\title{
Rituximab: Is it Possible to Link Both Autoimmune Haemolytic Anemia and Aplastic Anemia Regarding the Etiology and Management?
}

\section{Mina T. Kelleni}

Pharmacology Department, Faculty of Medicine, Minia University, Minia, Egypt

*Corresponding author: Kelleni MT, Ph, M, Pharmacology department, aculty of Medicine, Minia niversity, Minia, Egypt, Tel: 201200382422; Email: drthabetpharm@yahoo.com

Rec Date: June 28, 2016; Acc Date: June 29, 2016; Pub Date: June 30, 2016

Copyright: ( 2016 Kelleni MT. This is an open-access article distributed under the terms of the Creative Commons Attribution License, which permits unrestricted use, distribution, and reproduction in any medium, provided the original author and source are credited.

Citation: Mina Kellani T (2016) Rituximab: Is it Possible to Link Both Autoimmune Haemolytic Anemia and Aplastic Anemia Regarding the Etiology and Management? Gen Med (Los Angeles) 4: e110.

\section{Editorial}

In the past few years, rituximab has been recognized as a safe and effective emerging treatment for autoimmune hemolytic anemia (AIHA) [1,2]. Rituximab was also considered as a preferred secondline therapy of warm antibody hemolytic anemia in adults in some major European centers and it was shown that second-line treatment with rituximab led to response rates similar to splenectomy (approximately 70\%) [3]. Further, a lower dose of rituximab, with satisfactory safety and efficacy, was better than the conventional glucocorticoid in the treatment of elderly AIHA patients [4].

In 2002, rituximab was suggested as a first-line treatment for pure red cell aplasia after allogeneic bone marrow transplantation [5]. Three years later, rituximab was used successfully for treatment of a 73-yearold female with aplastic anemia, and the use of anti-CD20 monoclonal antibody in aplastic anemia was suggested to warrant further investigation [6]. Meanwhile, rituximab was shown to induce remission in a 68-year-old female with severe aplastic anemia induced by fludarabine and cyclophosphamide treating her B-cell chronic lymphocytic leukemia [7]. In 2011, rituximab was shown to induce remission in a 1-yr-old Japanese male infant developed hepatitisassociated aplastic anemia [8]. Recently, rituximab plus autologous hemotopoietic stem cell transplantation were used for the treatment of CD5 positive diffuse large B cell lymphoma with AIHA [9].

From my point of view, the great and successful usage of rituximab in the management of AIHA warrants more focused research on its full of potentials successful usage in aplastic anemia management. Following the footprints of rituximab, I expect more secrets to be revealed in the pathogenesis of aplasitc anemia; secrets that may connect the two hematological disorders as regard to the etiology and revolutionize their management in the near future.

\section{References}

1. Abadie K, Hege KM (2014) Severe refractory autoimmune hemolytic anemia with five-year complete hematologic response to third course of treatment with rituximab: a case report. Journal of medical case reports 8 : 175.

2. Reynaud Q, Durieu I, Dutertre M, Ledochowski S, Durupt S, et al. (2015) Efficacy and safety of rituximab in auto-immune hemolytic anemia: A meta-analysis of 21 studies. Autoimmun Rev 14: 304-313.

3. Dierickx D, Kentos A, Delannoy A (2015) The role of rituximab in adults with warm antibody autoimmune hemolytic anemia. Blood 125 3223-3229.

4. Zhang X, Sun J (2014) Lower dose of rituximab in the treatment of elderly autoimmune hemolytic anemia. Zhonghua Xue Ye Xue Za Zhi 35: 236-238.

5. Maschan AA, Skorobogatova EV, Balashov DN, Pashanov ED, Trakhtman PE, et al. (2002) Successful treatment of pure red cell aplasia with a single dose of rituximab in a child after major $\mathrm{ABO}$ incompatible peripheral blood allogeneic stem cell transplantation for acquired aplastic anemia. Bone marrow transplantation 30: 405-407.

6. Hansen PB, Lauritzen AM (2005) Aplastic anemia successfully treated with rituximab. Am J Hematol 80: 292-294.

7. Castiglioni MG, Scatena P, Pandolfo C, Mechelli S, Bianchi M (2006) Rituximab therapy of severe aplastic anemia induced by fludarabine and cyclophosphamide in a patient affected by B-cell chronic lymphocytic leukemia. Leukemia \& lymphoma 47: 1985-1986.

8. Takamatsu H, Yagasaki H, Takahashi Y, Hama A, Saikawa Y, et al. (2011) Aplastic anemia successfully treated with rituximab: the possible role of aplastic anemia-associated autoantibodies as a marker for response. European journal of haematology 86: 541-545.

9. Huang YQ, Zheng RJ, Wu RJ, Ma XD (2016) Rituximab plus Autologous Hemotopoietic Stem Cell Transplantation for The Treatment of CD5 Positive Diffuse Large B Cell Lymphoma with Autoimmune Hemolytic Anemia. Journal of experimental hematology 24: 722-726. 